\title{
Innovation Policy, Competence Creation and Innovation Performance of Foreign \\ Subsidiaries : The case of South Korea
}

\author{
Axèle Giroud \\ $\underline{\text { Axele.giroud@mbs.ac.uk }}$ \\ Yoo Jung Ha, Mo Yamin, and Pervez Ghauri
}

This is a pre-print (non-publisher's document). Please cite the published article:

Giroud, Axèle, Yoo Jung Ha, Mo Yamin, and Pervez Ghauri (2012), "Innovation policy, competence creation and innovation performance of foreign subsidiaries: The case of south korea," Asian Business \& Management, 11 (1), 56-78. (DOI: 10.1057/abm.2011.27).

\begin{abstract}
The aim of this contribution is to assess the impact of innovation policy on foreign subsidiaries' innovation performance. The South Korean government has implemented a series of policies to enhance the innovation capabilities of private firms, whether foreign, or locally owned. With more FDI in the country, the position of foreign subsidiaries as main actors for innovation is important. Yet the specific role of the South Korean innovation policies on facilitating and promoting innovation by foreign subsidiaries remains understudied. Further, the literature suggests that innovation activities of the subsidiary depend upon its strategic mandate. This paper's fundamental contribution, therefore, is to analyze the influence of innovation policies, and strategic mandates, on the innovation performance of foreign subsidiaries. Using data from the Korean Innovation Survey, a series of models are constructed explaining the innovation performance of 423 foreign firms in the Korean manufacturing sector. Results suggest that subsidiary innovation is primarily explained by its strategic role and competence-creating subsidiaries demonstrate higher levels of innovation performance. Innovation policy is found to influence more positively less innovative firms. Two types of policies are found to have a significant effect, namely technical support and tax incentives.
\end{abstract}


KEYWORDS: Innovation policy, MNCs, South Korea, Competence-creation, Subsidiaries, Technological development.

\section{INTRODUCTION}

Within the Multinational Company's (MNC) network, individual subsidiaries are augmenting their innovatory activities, and increasingly contributing to the resource-base of the firm. This trend is occurring as MNCs have started to locate innovation activities in multiple locations outside their home country, leading to a race in technologically capable host countries to attract their global R\&D activities, notably through the provision of preferential policy support. For the MNC, this means that innovation occurs not exclusively in the home country any longer, but also in host economies. For host country governments, attracting and promoting R\&D by subsidiaries located within their national borders matters because the entry of innovative FDI will generate social advantages for the local industries in the form of knowledge spillovers (Casson, 2007: 308), and with enhanced innovation, countries increase their longterm economic growth (Ghauri and Yamin, 2009).

MNCs contribute to the local innovation environment through FDI and technological spillovers and foreign subsidiaries, in return, contribute to the multinational network by creating valuable knowledge locally, and sharing such knowledge with the MNC (Cantwell and Piscitello, 2002, Almeida and Phene, 2004). The literature emphasizes the importance of resources in the local area for innovation within foreign subsidiaries (Pearce, 1999), the superior capacity of the MNC to mobilize knowledge, and innovate, because of its greater access to more knowledge networks (Frost, 2001, Phene and Almeida, 2003). The literature also points to the importance/benefit of a local subsidiary possessing its own capabilities (Birkinshaw and Hood, 1998). The literature has also drawn attention to the superior innovative capabilities of competence creating subsidiaries (Pearce, 1999, Yamin, 1999, Cantwell and Mudambi, 2005), and their enhanced ability to then contribute to the local economy because of locally drawn resources (Marin and Bell, 2006).

Studies explaining the development of subsidiaries' capabilities focus primarily on the relationship with the headquarters (Yamin and Andersson, 2011), and local embeddedness as an explanation for knowledge development and competence creation (Frost et al., 2002, Foss and Pedersen, 2002, Cantwell, 2009). Thus, while the role of the environment on the creation, and strengthening, of innovation activities by foreign subsidiaries has been empirically demonstrated, there is little known about the specific role of government policies on subsidiaries' innovation. Two trends indicate that this issue has become important. First, MNCs are increasingly locating innovation in overseas markets and perceive subsidiary innovation 
as major contribution to the firms' resources, and, second, many governments are keen to attract the R\&D activities of MNCs within their national boundaries (Meyer-Krahmer and Reger, 1999). Cantwell and Mudambi (2000: 142) find that long-term measures under the umbrella of a country's national innovation system are likely to be more effective in terms of supporting innovatory activities in subsidiaries, than short-term incentive measures aimed at attracting R\&D activities. For this reason, the authors believe that national innovation policies impact upon subsidiary innovation, but there is a lack of empirical studies demonstrating whether subsidiary innovation is indeed enhanced by the host country' innovation policies.

This paper focuses on $R \& D$ activities by foreign manufacturing subsidiaries but differentiates between asset augmenting FDI and asset exploiting FDI. In doing so, the aim is to fill the two research gaps identified. They are, firstly, to what extent does the host country's innovation policy influence foreign subsidiaries' innovation activities? Secondly, does the impact vary depending whether the subsidiary is competence creating?

Focusing on foreign subsidiaries, and the type of policy instruments the host country government may deploy, studies indicate that inward FDI policy (with regards to taxation, financing supports, and other infra-structural supports) would directly influence the entry decisions of MNCs into the host country (Mudambi and Mudambi, 2005). Once the subsidiary starts to operate R\&D facilities in the host country, however, the performance of the foreign-owned R\&D facilities and the extent of knowledge spillovers are likely to be influenced by the host country's innovation policy, as well as initial inward FDI policy. In the case of South Korea, inward FDI promotion, and national innovation policy, can complement each other to harness the potential of innovation-intensive activities by MNC subsidiaries. The country's FDI policy has undergone two major changes in the 1990s and early 2000s: firstly, it has removed the remaining policy barriers to FDI inflows. Secondly, the current innovation policy structure, seemingly indiscriminately favoring foreign and domestically-owned firms, tries to integrate MNC R\&D centers into the national innovation system.

Korea recently engaged in active innovation policies because it experienced a decrease in corporate $R \& D$ spending after the Asian financial crisis. As a response, the Korean government increased public R\&D budgets, promoted the development of a technology-based SME sector, and implemented targeted measures such as facilitating venture start-ups and growth, providing finance (through funds and tax incentives) and research support ( $\& \& D$ funding, tax waivers, tariff exemptions for $R \& D$ equipment) (OECD, 2009b: 11). These measures have been successful, with numerous R\&D labs opening throughout the country, yet there are no studies investigating their specific impact on foreign firms' innovation activities. 
To address these research gaps, firm-level considerations behind innovation, focusing on sources of innovation for MNCs' subsidiaries, are combined with the national policy context and the political economy of firm-government relations in the case of South Korea. The main contribution of the paper lies in the identification of the impact of government policies on subsidiaries' innovation performance. Using data from the Korean Innovation Survey, the impact that government policies have had on foreign firms' innovation are tested.

The paper begins with a brief assessment of the national innovation system in Korea, before a review of the literature on factors explaining innovation by foreign subsidiaries. In the methodology section, models are presented to compare the role of government policies and subsidiary strategic orientations in explaining innovation activities. The paper ends with a discussion of the results, key contributions, and policy implications.

\section{FDI, GOVERNMENT POLICIES AND INNOVATION IN SOUTH KOREA}

The economic development of South Korea was characterized by autonomous technological development, in contrast with different models of development followed in other East Asian countries, such as strategic FDI-dependent or passive FDI-dependent model (Lall, 2003). Qualitative studies focusing on the firmlevel technology strategies demonstrate that technological development in Korea begun with the early reverse engineering phase in the 1960s and 1970s. In the 1980s, Korean companies emerged as major Original Equipment Manufacturers (OEM) in global production networks of multinational manufacturers (Kim, 2003, Hobday, 1995). While operating as OEMs, many Korean companies also strived to develop their own design and brands, which led to their successful ability, in the 1990s, to upgrade to the status of Original Design Manufacturers (ODMs) with their own established technology, design, and global brands. Such industry-level achievements facilitated country-level technological development. In 2007, Korea's domestic R\&D expenditures as a percentage of GDP were the fourth highest amongst OECD countries, next to Sweden, Finland, and Japan. In 2005, the total number of patents reported in Korea surpassed that of the UK and France. Although macro-level indicators do not provide details on the types and complexity of the technology, there is no doubt that South Korea has achieved technological development at an impressive speed, and as a result, MNCs seeking international knowledge sourcing can find the countryspecific assets of South Korea attractive (Lee and Rugman, 2009).

Table 1 Number of patents reported: Korea and other OECD countries 


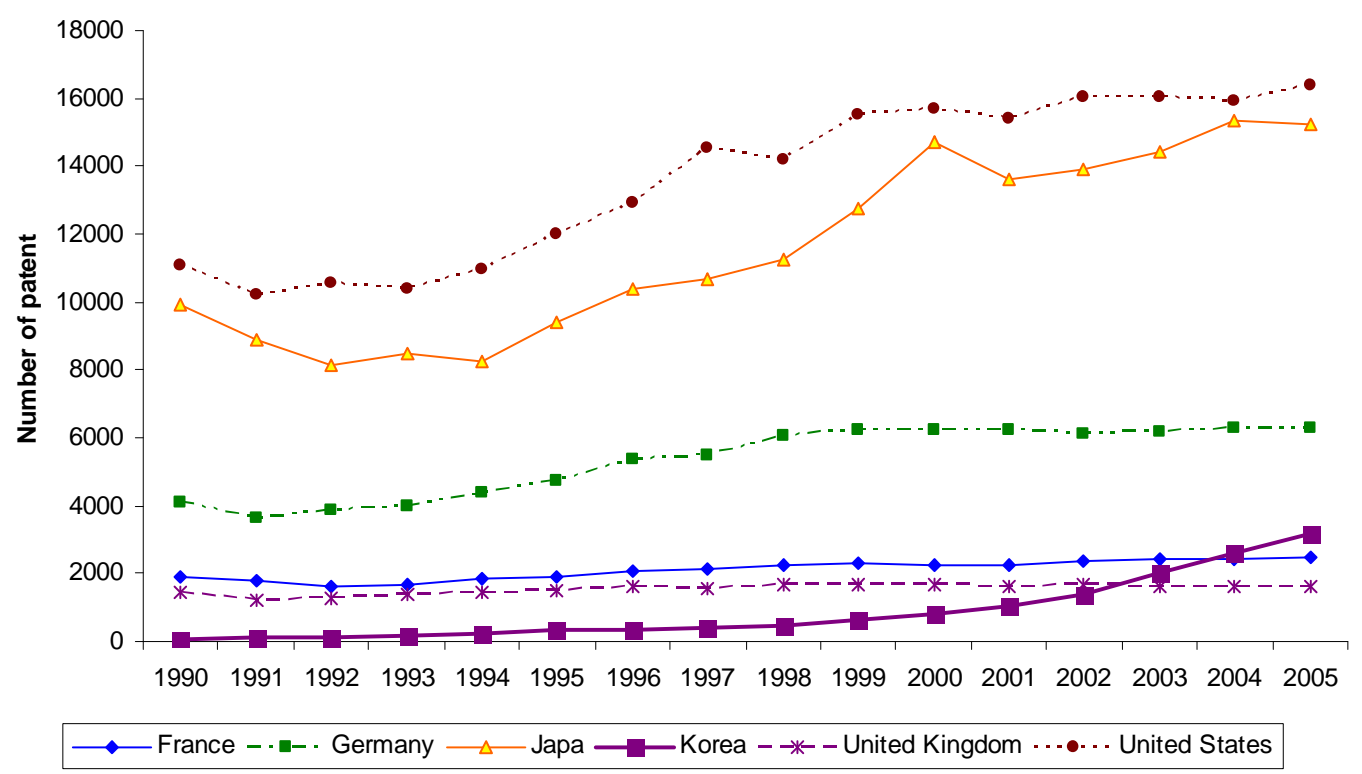

Source: OECD (2009a)

The Korean government liberalized inward FDI entry in the 1990s by adopting a five-year FDI liberalization plan in 1993, which culminated in major FDI liberalization in 1996, in conjunction with Korea's entry into the OECD. The liberalization drive resulted in the Foreign Investment Promotion Act of 1998. A government report published by Korea Trade-Investment Promotion Agency (KOTRA, 2007) claims that, as of 2007, explicit restrictions on inward FDI can be found in only two sectors - television and radio broadcasting - although the OECD considers that there exists scattered barriers against foreign ownership in 26 other sectors (Jones and Yoon, 2008, KOTRA, 2007). The wave of inward FDI liberalization was followed by the promotion of global $R \& D$ centers during the Administration of President Roh Moo-hyun (2003-2008). In 2003, the Foreign Investment Promotion Act was revised so that R\&D facilities with more than 20 full-time $R \& D$ staff and the value of investment higher than five million US dollars became eligible for policy support for inward FDI.

MNC subsidiaries can, in principle, benefit from the national innovation policy. Following the Asian crisis in 1997 and a decrease in private firms' R\&D spending, the Korean government has increased public $\mathrm{R} \& \mathrm{D}$ budgets, promoted the development of a technology-based SME sector, and implemented targeted measures (OECD, 2009b). To date, these measures have been successful, leading to an increase in the number of corporate R\&D labs, and additional support to SMEs. 
The inclusion of R\&D projects in the policy target made it possible for innovation-oriented investment projects to benefit from policy support. Such policy support includes tax incentives to reduce tax burdens, financial incentives to facilitate access to finances for new investment projects, and other indirect market incentives that aim to indirectly improve the profitability of business (KOTRA, 2007). Since 2004, cash grants have been available for foreign investors in high-technology industries. The initial eligibility conditions, mostly about the size of the R\&D unit and the value of the investment, have been relaxed progressively. By the end of 2007, the requirement on the investment value was removed and the minimum size of a R\&D unit lowered to ten R\&D staff.

Both foreign and domestic $R \& D$ facilities can apply for the $R \& D$ centre status. According to the Technology Support and Development Act, once the application is approved, facilities become eligible for government policy support (KOITA, 2007: 9). Policy instruments for innovation promotion include 1) tax incentives, 2) financial support, 3) human resource development, 4) legal and institutional infrastructure support, 5) public procurement, and 6) indirect technological support (Shin et al. 2006). In terms of budget ratio allocated to each policy instrument, tax incentives, financial support, and public funding in the form of R\&D subsidies, play the most important part in national technology support and development. Policies addressing the technological needs of private companies receive less funding, although the size of budget does not necessarily reflect the actual impact of policies, nor the nature of support for individual companies. Despite this increase in government support, there are no studies focusing on its impact on MNCs located within South Korea, and it is unclear whether those policies influence innovation performance by foreign subsidiaries.

\section{SUBSIDIARY INNOVATION, COMPETENCE CREATION AND GOVERNMENT POLICIES}

\section{Explaining Subsidiary Innovation}

Over the past two decades, the traditional view of value creation within the MNC has evolved, with less focus on the headquarters, and more on individual subsidiaries (Yamin and Andersson, 2011). Some foreign subsidiaries access external resources to create firm-specific, competitive advantages by virtue of location (Cantwell, 2009). Other subsidiaries, in addition to utilizing local resource also develop unique resources, which act as a determinant for innovation (Pearce, 1999, Phene and Almeida, 2003). With time, competence creating subsidiaries can transfer valuable knowledge back to the MNC (Yamin, 1999, Yamin and Otto, 2004). Comparing relationships with the headquarters, one can further differentiate between 
competence creating or competence exploiting subsidiaries. The two broad mandates are the exploitation mandate (in this case, the subsidiary conducts R\&D to exploit existing MNC knowledge) or the exploration mandate (the subsidiary conducts R\&D to augment existing MNC knowledge). Cantwell and Mudambi (2005: 1121) find that $R \& D$ intensity differs depending on whether the subsidiary has a competence-creating or exploiting mandate. This suggests that subsidiary mandate influences its innovation performance.

Although all subsidiaries can access and use knowledge from both the MNC and the host country, subsidiary roles significantly influence subsidiary innovation. The business network literature has defined subsidiary embeddedness as mutual adaptations in developing processes and products between the subsidiary and a number of local counterparts (Forsgren et al., 2005). Depending on the mandate of the subsidiary, the extent of the local network will differ; the competence creating mandate suggests a strong network (for instance with universities and other scientific and technology centers), whereas the competence exploiting mandate suggests a less extensive local network. The outcome of local embeddedness is likely to differ with the mandate of the subsidiary, particular with respect to R\&D and innovation.

Beyond the MNC itself and subsidiary competences, the host country environment influences subsidiary innovation through a number of ways. The national institutional context explains patterns of innovation across countries, and success of the innovation policy involves a suitable alignment between policy design and policy objectives (Bodas Freitas and Tunzelmann, 2008). Governments are generally keen to promote and attract R\&D activities within their national boundaries (Cantwell and Mudambi, 2000), in the case of South Korea, the government has increased national $R \& D$ resources in order to improve the national innovation system (Chung and Shavinina, 2003). A nation's capacity for innovation is the result of combined individual firms' capabilities as well as linkages amongst those firms (Lundvall, 1992). Within many host countries, foreign subsidiaries have access to, and benefit from, innovation policies in place. There is little in the literature, however, explaining the impact of such policies on subsidiary innovation. Cantwell and Mudambi (2000: 142) find that long-term measures under the umbrella of a country's national innovation system are likely to yield higher returns than short-term incentive measures aimed at attracting $R \& D$ activities.

To fill the research gaps identified, this study combines firm-level considerations behind innovation with the national policy context and the political economy of firm-government relations. In the next section, the hypotheses are developed. 


\section{Government policies and subsidiary innovation}

It is widely accepted that the internal embeddedness in its own intra-MNC network (Ghoshal and Bartlett, 1988), and the external environment, contribute to the innovation of the subsidiary (Frost et al., 2002, Forsgren et al., 2005). Within the external environment, business relationships, the overall level of competitiveness (Cantwell and Mudambi, 2005, Cantwell, 2009), and the interaction with local government research institutions, can influence the subsidiary' innovation (Santangelo, 2009). While the role of formal or regulative institutions, such as government policies, are crucial to explaining firms' activities (North, 1990), and such institutions are essential for the efficient production of particular goods and services; little is known about the impact of policies on subsidiaries' innovation.

The context in which the foreign subsidiary operates, can be assessed using the institutional theory. This theory helps in understanding the ways through which the liability of foreignness for the MNE occurs as a result of institutional differences. Institutional differences lead to a lack of familiarity with the foreign environment in which the MNE has operations, creating relational hazards (Eden and Miller, 2004), and difficulties in coordination across markets. When the institutional distance is large between the home and host environments, the economic and social costs of learning from the new environment is enhanced (Eden and Miller, 2004). Thus, institutions have an influence on both the location of MNC affiliates and on their motivation and conduct (Kostova, 1999).

In particular, governments can influence the knowledge-creating activities of MNCs through the national innovation system (Lundvall, 1992). Innovation policies are aimed towards the overall economic development objectives of the country. It has been argued that policies aimed at directly influencing innovatory systems and capacity can have varying degrees of success (Dunning and Lundan, 2008: 385), if the long-term development objectives of the country are not in line with the existing capabilities of firms within this country. Many studies focus on the locational determinants of R\&D by MNCs (Narula, 2002, Guimón, 2011, Cantwell and Mudambi, 2005) on initial attraction of FDI (Lim, 2008) or on the interaction effect with local actors such as suppliers (Giroud, 2006). In this paper, we focus on microeconomic policies of innovation.

The reason for this choice is that a subsidiary can draw advantages from within the firm itself and/or externally in different environments. On the one hand, the subsidiary can benefit from internal ownership advantages by importing capabilities embodied in organizational practices (Zaheer, 1995, Gaur and Lu, 2007) of their parent enterprises or by internal, isomorphic mechanisms that emerge through cross-border experiences (Rosenzweig and Singh, 1991: 346). On the other hand, the subsidiary can benefit from 
enhanced local isomorphism, mainly by imitating the best organizational practices of local firms in the host environments (Francis et al., 2009, DiMaggio and Powell, 1983, Rosenzweig and Nohria, 1994).

Several dedicated innovation policy instruments have been found to positively influence the innovation success of firms by facilitating local isomorphism mechanisms, and by minimizing some of the related social and economic costs of innovation in foreign environments. Focusing on Korean electronic parts and mechanical industries, Lee and Park (2006: 1052) find that government support in the early stage of R\&D (that is the stage of initial investment by the firm in R\&D facilities) improves the chances of success of a firms' innovative activities. This can be because efforts to help firms maintain an appropriate R\&D scale are needed, especially when technological risks linked to imperfect competition and uncertainty in the market can inhibit firms' investment in R\&D. This enhances the need for government support toward product innovation, and technology-push innovation. In the case of Germany, Aschhoff and Sofka (2009), demonstrate the positive outcome of public procurement. These studies do not focus on foreign subsidiaries as such, but show the impact of innovation policies. For this reason, it is posited that innovation policy will have a positive influence on innovation performance of foreign subsidiaries:

Hypothesis 1: Government innovation policy has a positive effect on the innovation performance of the foreign subsidiary.

\section{Types of subsidiaries: Competence creation or exploitation}

Competence creating subsidiaries are sub-units of the MNC that have gained a more creative role by generating new products or services. Such creation is the result of the comparative advantage in innovation conducted by the subsidiary (Cantwell and Mudambi, 2005, Pearce, 1999, Forsgren et al., 2005). Given that market knowledge and commitment increase with the length of operation in the host market, external embeddedness contributes to the ability of the subsidiary to become competence creating (Cantwell and Mudambi, 2005), and in particular its ability to accumulate innovation capabilities (Frost, 2001). Competence creating subsidiaries can then share their knowledge with other units of the MNC, thus, the ability to create or develop competences determines which subsidiaries will be givers (of knowledge) and which will be receivers in the corporate system (Andersson et al., 2002).

The ability of the subsidiary to transform knowledge is dependent upon the subsidiary characteristics, its resource-base, and capabilities. While the subsidiary often begins by sourcing knowledge internally within the MNC network, over time, it can also generate its own resources and source knowledge externally 
within the host economy (Cassiman and Veugelers, 2002, Roper et al., 2008). This allows the subsidiary to develop competences, transforming this knowledge into new products and processes.

There exist benefits to the action of competence creation within the subsidiary (Cantwell and Mudambi, 2005), namely by achieving a more influential position within the overall multinational network (Forsgren et al., 2005). With innovatory capabilities, the subsidiary can transform knowledge into new products and processes, and demonstrate innovation output, such as a larger number of patents. The first assumption is, therefore, that the strategic orientation of the subsidiary (i.e. whether it is competence creating or competence exploiting) influences the innovation performance of the firm, and in particular there is a positive relationship between competence creation and innovation performance. Indeed, to create competence, the subsidiary demonstrates the ability to engage in specialized activities (concerning a product, a production process, or specific functions), this in turn leads to enhanced innovation activities and performance.

Hypothesis 2: There is a positive relationship between a foreign subsidiary's competence creating orientation and its innovation performance.

In South Korea, policy instruments for innovation promotion at the level of the firm include tax incentives, financial support, human resource development, legal and institutional infrastructure support, public procurement, and indirect technological support (Shin et al. 2006). While such policies may have differential impacts on stimulating innovation by subsidiaries, there is reason to expect that beneficial impacts are likely to be greater for competence creating subsidiaries

For subsidiaries with higher competence creation competences, and in particular those that are highly innovation intensive, the fulfillment of innovation projects requires greater external embeddedness. This poses additional challenges to competence creating subsidiaries because of the greater pressure of conformity towards the institutional context. The degree of local embeddedness towards innovation purposes is related to the ability to prioritize ideas and align those with the firms' resources (Sofka, 2006). In particular the subsidiaries' deeper embeddedness is likely to give it a better ability to discriminate between which provide a better enhancement for innovation, and also, be better placed to benefit for some policies. In this context, we suggest that innovative subsidiaries are more likely than others to benefit from preferential normative institutions such as policy support by the host country government. Thus:

Hypothesis 3: The positive effect of government innovation policy on innovation performance will be stronger for subsidiaries with a competence creating orientation. 
As has been mentioned in the previous section, in South Korea, policy instruments for innovation promotion at firm level include tax incentives, financial support, human resource development, legal and institutional infrastructure support, public procurement, and indirect technological support (Shin et al., 2006). The largest budget ratio is allocated to tax incentives, financial support and public funding (R\&D subsidies), in comparison to other policies (such as information and technical support, or training). Despite the shortage of studies on their impact for foreign subsidiaries, evidence shows, that public procurement (Aschhoff and Sofka, 2009), and early R\&D support (Lee and Park, 2006), are beneficial. From the perspective of the innovative foreign subsidiary, one can anticipate that, firstly, information and training provide support to the firm in addressing unfamiliarity about new institutional environments. Secondly, funding, technical and procurement support help in reducing relational hazards that would inhibit the subsidiary's access to local financial institutions, public research resources, and local clients, and thirdly, tax incentives can reduce the overall cost of doing business facing institutional distance. In the context of competence creating subsidiaries, it is likely that some policies will be more effective in enhancing innovation performance. Thus, basic support, such as the one provided by training and human resource policies, is expected to have a relatively low marginal benefit, since these subsidiaries may have strong human resources already. On the other hand, financial and tax related benefits are likely to be more effective, because they will provide flexibility to the firm in its use of resources, and in its ability to alleviate the obstacles it perceives as constraining its innovation programmes. It is, therefore, suggested :

Hypothesis 4: Financial-based innovation policy instruments have a greater positive impact on innovation performance of subsidiaries with a competence creating orientation, than other policies.

In the next section, the methodology is presented and adopted to test the two hypotheses. The section begins with a presentation of the data used, before introducing the models and discussing the results.

\section{METHODOLOGY}

\section{Data}

The Korean Innovation Survey (KIS) is used for the manufacturing sectors in 2002 and 2005 to test the hypotheses. KIS 2002, reports firms' innovation activities between 1999 and 2001, while KIS 2005, covers the period from 2002 to 2004. This data set is prepared by the Science and Technology Policy Institute (STEPI) under the Government of the Republic of Korea. The KIS is part of the OECD Oslo's Manual, which overseas innovation surveys in different countries. KIS is administered under the Law on National Statistics in the Korean context. Participating firms are asked about the importance of knowledge 
sources, the acquisition of technology, technological cooperation, purposes and barriers to innovation, as well as general information about innovation. The sample of this survey is firms that have introduced at least one innovation within three years from the survey period. From the original data, foreign subsidiaries are extracted, which are defined as those with foreign capital participation ratio higher than $20 \%$. Our industry case is the manufacturing sectors as classified in the NACE 2-digit system. The dataset contains a total of 423 foreign firms. A pooled-cross-section data, was constructed which represents two different periods but is not a panel data (Wooldridge, 2009). This pooled-cross section data allows us to examine the shift of innovation performance over time. Only a very limited number of firms participate in the survey each year, which supports our assumption that each set of cross section (KIS 2002 and KIS 2005) is independent, with not identically distributed (i.n.i.d) observations (Wooldridge, 2002: 129).

\section{Variables and measurement}

\section{Dependent variable}

The dependent variable is represented by the innovation performance of a foreign subsidiary. It is measured by the number of product patents a firm applied for over the three-year period prior to the survey. Using the three-year cumulative indicator of innovation output, it is argued that our measurement addresses the time lag required for a firm to transform internal and external innovation inputs into actual innovation output. Patents have previously been used as a measure of innovation performance (Crespi et al., 2007), and are therefore used in our study as the dependent variable.

\section{Independent variables}

Government Policies: Data about detailed innovation policy instruments are obtained from the CIS survey. Managers of foreign subsidiaries provided answers to questions related to the effectiveness of government policy about 1) training support, 2) information support, 3) technical support, 4) public procurement opportunities, 5) public funding, and 6) tax incentives. These are perceptual measures, indicating senior managers' views on the impact of relevant policies on their innovation activities. Responses are reported at a five-point Likert scale, with zero when the respondent answered 'not applicable'. Both the overall policy effect and the effect of sub-policies in our model are analysed. For the overall policy effect, an aggregate policy effect variable is used (combining answers for all 6 items). Following Mudambi \& Mudambi (2005), a factor analysis is conducted to compress six policy items into one latent component. This single latent variable explains $59.023 \%$ of total variance of the underlying component, and it is used as a proxy for the overall policy effect. 
Subsidiary Innovation Activities: To distinguish between competence creating and competence exploiting subsidiaries, a series of ten questions related to innovation activities by the firm is used. A factor analysis based varimax rotation method with Kaiser normalization is used to extract two components (showing a cumulative sum of loadings of $84.00 \%$ ). The first component is closely associated with activities based on existing capabilities of the firm, indicating that firms within this category predominantly engage in competence exploiting innovation activities (highest loadings are accounted for by improvement in the work environment and cost reductions; the component accounts for $47.88 \%$ of total variance). In this case, firms are named Competence Exploiting Subsidiaries. The second component represents firms engaging in competence creating innovation activities (highest loadings are accounted for by product diversification, new product introduction and market power expansion; the component accounts for $36.12 \%$ of total variance). In this case, firms are named Competence Creating Subsidiaries.

A number of control variables are used in the models. The control variables are the R\&D intensity of the subsidiary (measured by the number of R\&D staff and R\&D expenditure), technological intensity of the industry in which the firm operates (we use the OECD definition, also used by Schmiedeberg (2008: 1497) to categorize firms in terms of their technology intensity), the intensity of local business networks relationships (this is a perceptual measure whereby managers assessed on a 5-point likert scale the influence of local business partners on their innovation activities), the year in which the company answered the survey (this dummy indicates whether the firm answered the questionnaire in the 2002 or 2005 survey), the size (in terms of overall employment), the entry mode (assessed by the percentage of foreign capital in the company) and the age of the firm (in terms of the number of years of establishment).

The dependent, independent and control variables are presented in Table 1.

\section{Insert Table 1 Here}

To test the hypotheses, a series of negative binomial regression models are developed. The baseline model is adopted from the conventional knowledge production function, which exhibits the relationship between a company's internal resources, more precisely, $R \& D$ expenditures and $R \& D-r e l a t e d$ personnel and innovation outputs (Crespi et al., 2007). By adding a competence and a policy variable as independent variables, their role on innovation performance in the production function can be decomposed. The role of policy support on firm's innovation performance is assessed while the effect of internal resources is held constant. Our estimates for those coefficients are heterogeneity-robust. Models 1 and 2 assess the role of subsidiary competence and overall innovation policy (see Table 2). Models 3 and 4 consider the 
interaction of those two variables and individual types of policies and their impact on the firm performance (see Table 3).

\section{Insert Tables 2 \& 3 Here}

\section{ANALYSIS AND RESULTS}

In Models 1 and 2, the relationship between subsidiaries' innovation performance and overall government policies is assessed. The coefficient for the policy variable is positive and significant in Model 1, but not in Model 2, when the subsidiary role is tested for. While the coefficient for CC (1.495) is slightly higher than the one for CE (1.210), both subsidiary roles related to innovation are positively associated with the subsidiary-level performance. Model 2 shows that the positive policy effect is endogenous to the innovation type and the subsidiary's role in the MNC. Overall, our results support Hypotheses 1 and Hypotheses 2, but the predominant role of the subsidiary is noted.

The interplay between innovation policy and the subsidiary's role in MNC innovation is elaborated in Models 3 and 4. In Model 3, interaction terms are created by multiplying the policy variable and each subsidiary role variable, CC and CE. Our results show that the effect is negative and stronger for competence-creating subsidiaries, thus Hypothesis 3 is not confirmed. This indicates that innovation policy in a host country can have a negative effect on the innovation activities of foreign investors which are already playing a part in the MNC innovation.

The literature predicts a substitution effect by innovation policy (Aschhoff and Sofka, 2009), and our finding provides a useful example. We find that less innovative firms are better able to benefit from innovation policies. This may indicate that for the more innovative subsidiary, innovation policy can have a substitutive effect and even crowding out effect rather than enhancing these firms' innovation performance.

To differentiate between various types of policies and test Hypothesis 4, dummy variables representing different policy instruments are introduced in Model 4. Interaction terms are computed by multiplying these dichotomous variables with the CC and CE subsidiary variables. This enables us to identify which types of policies managers perceive, to be an influencing factor on their innovation performance. Results indicate that the interaction term between Technical support and CE role has a positive and significant effect on innovation performance. This can be because access to technical support facilitates the foreign subsidiary's efforts to adapt MNC-level capabilities and competences to the local context. Tax incentives improve innovation performance of a firm with the $\mathrm{CC}$ role. 
The results are consistent with the existing knowledge regarding the impact of policies on firms' innovation discussed in the section on South Korea. Tax incentives and indirect technological support are identified as having the most significant effect on firms' innovation (Shin et al., 2006). This paper contributes further to existing knowledge in two ways; it provides evidence that foreign subsidiaries respond in a similar way to locally-owned firms (inasmuch as technical support and tax incentives have a clear influence on innovation activities of the firms), and it differentiates the effect of policies according to subsidiaries' strategic orientation.

Other types of innovation policies, such as public procurement support, are not found to have a significant impact on foreign subsidiaries' innovation performance. As public procurement support was only recently introduced as a new innovation policy instrument by the Korean government, it is possible that it will take time for managers to perceive its impact on their firms' innovation activities. Other policy types, such as direct $R \& D$ subsidies, are not found to have a significant impact. This could be because locally owned firms are the major recipient of these incentives, rather than foreign-owned firms.

Finally, the use of control variables in our models confirm known factors influencing foreign subsidiaries' innovation, but in the case of South Korea. Firstly, firm characteristics such as R\&D staff and expenditure, entry mode, size and age have a significant impact on subsidiary innovation performance. Secondly, both the technological intensity of the sectors in which the firm operates and the local business network influence subsidiary innovation performance.

These results confirm the role of local relationships and embededdness within the economy as the key determinant of subsidiary innovation performance in the case of South Korea. Foreign subsidiaries operating under the joint venture mode with a local partner and those with close business networks have higher innovation performance. This illustrates the positive influence of internal and external sources of knowledge on foreign subsidiaries' innovation (Forsgren et al., 2005, Ghauri et al., 2005). In terms of size and age, our results confirm those of other studies, as the subsidiary evolves and accumulates resources and capabilities over time (Birkinshaw and Hood, 1998), leading to enhanced innovation performance.

\section{DISCUSSION AND CONCLUSIONS}

This study contributes to the literature by investigating the role of innovation policy on explaining foreign subsidiaries' innovation performance, in the case of South Korea. The empirical analysis provides key results. These are:

1) Innovation policy does influence subsidiaries' innovation performance overall, even though 
2) The subsidiary's strategic role is more prominent in explaining technological value creation by the firm;

3) Policy can, in part, create challenges to the innovation process for $\mathrm{CE}$ and $\mathrm{CC}$ subsidiaries;

4) Not all types of innovation policies contribute to foreign subsidiaries' innovation performance to the same extent, with technical support and tax incentives having the strongest effect.

This study confirms and extends existing knowledge on factors explaining subsidiary innovation performance and on the impact of innovation policies on firms. Current empirical studies in other countries have reported mixed effects of the effectiveness of innovation policy instruments (e.g. Aschhoff and Sofka, 2009). Shin et al. (2006) concludes that companies are likely to benefit most from tax incentives, followed by legal and institutional infrastructure, indirect technology support, financial support, and human resource development; however, studies on innovation policy in South Korea do not present evidence on foreign firms (KOTRA, 2007, Shin et al., 2006, OECD, 2009b). Our results add to current knowledge, showing that foreign subsidiaries respond similarly to innovation policy compared to locally-owned firms, and that technical support and tax incentives have more impact.

From a theoretical perspective, the Institutional theory emphasizes institutional pressures relative to firms' active responses (Oliver, 1991), rather than pointing at active agency seeking self-interests. For this reason, the institutional theory does not fully predict the case in which firms' behaviors are not aligned with policy-markers' expectations. Our results demonstrate that firms do not always conform to predictions of the impact of formal institutions. Instead, own resources (or development of core competences) determine innovation performance, with varying responses to local institutional contexts. For this reason, comparing the effect of policy types with subsidiary roles, our results suggest that certain types of subsidiaries will be more sensitive to certain types of policies. Combined with the evidence that firms that have operated longer in South Korea and that are better embedded with local business networks, the ambiguous effect of innovation policy on foreign subsidiaries suggest that firms need to overcome the costs associated with liability of foreignness in a host country on their own.

Hence, one of the key contributions of this paper is to place innovation policy in perspective. While the role of government is established, it transpires that it is the position of the firm within the overall strategic objectives of the MNC (Birkinshaw and Hood, 2001, Yamin and Andersson, 2011), even though the local environment also plays a role (Cantwell, 2009). Subsidiary specific characteristics are also clearly found to influence innovation performance in our sample, confirming extant literature (Yamin, 1999). 
Given these contributions, some policy recommendations can be drawn. Considering recent policy developments in Korea in terms of inward FDI promotion and national innovation policy, we suggest that: 1) the preference for sizeable investment is lifted so that both small and large projects can benefit from tax incentives and other policy supports for inward FDI. 2) Supply-side policy schemes within the framework of national innovation policy, such as indirect technology support, are more diversified and are expected to address foreign subsidiary's immediate concerns regarding innovative activities in the host country, and 3) demand-side policy supports, such as procurement policy, have been recently introduced and the effectiveness is not seen amongst foreign subsidiaries. Since the government can influence innovation performance of foreign subsidiaries, depending on the mandate of the firm, some targeted efforts, in particular in terms of provision of technical support and or tax incentives, can yield better results. As such, the emphasis on different types of policy innovation incentives can influence the firm differently.

A key finding of the present study is that policy stimulants impact on the $\mathrm{CC}$ and $\mathrm{CE}$ subsidiaries in different ways. Generally, in the South Korean context, the impact of public policy support is somewhat greater for competence exploiting subsidiaries in terms of tax incentives. This suggests those firms draw larger benefits from local government support, as well as benefitting from the effective development of business network with key partners in their own and related industries. In contrast, the impact of publicly provided technical support is greater for subsidiaries with a competence exploiting orientation. This suggests that management of these subsidiaries should be particularly sensitive to the overall policy and regulatory environment in host countries, as they may miss out on other potential benefits.

To conclude, the objective of this paper was to examine the extent to which innovation of a firm can be assisted by the host country's innovation policy, with the specific case of South Korea. The main finding of this paper is that innovation policy is overpowered by the initial motivation of a company, as this is a primary explanatory factor for innovation performance. A survey conducted by KOITA (2007) found that foreign subsidiaries running R\&D facilities in Korea demanded more tax incentives and public funding. We contribute to this finding by demonstrating that the strategic orientation of the foreign subsidiaries also influences the preferred type of policy instruments.

The results suggest that the impact of policy varies depending on how innovative the firm is prior to receiving government support, however, there are two main limitations to our study. First, the case of South Korea may differ from the experience of foreign firms in other countries, and our sample focused solely on one sector, the manufacturing sector. Second, while evidence is found that specific types of policies influence foreign firms in a similar way to locally-owned firms, those two types of firms were not 
compared and contrasted within our sample. This points to the need for more evidence to understand better the reasons why a company would be opportunistic in response to a certain policy instruments. 
Table 1 Variables, measurements and descriptive statistics

\begin{tabular}{|c|c|c|c|c|c|c|}
\hline Variable & Obs & Mean & Std. Dev. & Min & $\operatorname{Max}$ & $\begin{array}{c}\text { Cases } \\
\text { (1) }\end{array}$ \\
\hline \multicolumn{7}{|l|}{ Dependent variable } \\
\hline Patent & 419 & 17.24 & 58.30 & 0 & 997 & \\
\hline \multicolumn{7}{|c|}{$\begin{array}{l}\text { Components in a basic knowledge } \\
\text { production function }\end{array}$} \\
\hline R\&D Expenditures (2) & 387 & 3962.24 & 36985.08 & 0 & 600000 & \\
\hline R\&D Staff & 369 & 25.96 & 67.08 & 0 & 860 & \\
\hline \multicolumn{7}{|l|}{ Innovation policy instruments: } \\
\hline Taxation & 417 & 1.28 & 1.83 & 0 & 5 & 149 \\
\hline Public funding & 417 & 0.96 & 1.61 & 0 & 5 & 131 \\
\hline Public procurement & 419 & 0.95 & 1.66 & 0 & 5 & 114 \\
\hline Technical support & 419 & 0.70 & 1.39 & 0 & 5 & 98 \\
\hline Information support & 420 & 0.95 & 1.59 & 0 & 5 & 123 \\
\hline Training & 420 & 0.93 & 1.57 & 0 & 5 & 121 \\
\hline \multicolumn{7}{|l|}{ Firm-specific competences: } \\
\hline New product introduction & 417 & 2.21 & 2.09 & 0 & 5 & \\
\hline Product diversification & 422 & 2.30 & 2.04 & 0 & 5 & \\
\hline Market power expansion & 421 & 2.63 & 2.17 & 0 & 5 & \\
\hline New market initiative & 419 & 2.41 & 2.02 & 0 & 5 & \\
\hline Flexible production & 421 & 2.15 & 1.97 & 0 & 5 & \\
\hline Labour cost reduction & 421 & 2.25 & 2.01 & 0 & 5 & \\
\hline $\begin{array}{l}\text { Other production cost } \\
\text { reduction }\end{array}$ & 421 & 2.42 & 2.10 & 0 & 5 & \\
\hline Quality improvement & 421 & 2.78 & 2.19 & 0 & 5 & \\
\hline $\begin{array}{l}\text { Work environment } \\
\text { improvement }\end{array}$ & 419 & 2.29 & 1.99 & 0 & 5 & \\
\hline Institutional change & 419 & 2.03 & 1.94 & 0 & 5 & \\
\hline \multicolumn{7}{|l|}{ Control variables } \\
\hline Low-tech & 423 & 0.10 & 0.30 & 0 & 1 & 42 \\
\hline Mid-low tech & 423 & 0.13 & 0.34 & 0 & 1 & 55 \\
\hline Mid-high tech & 423 & 0.31 & 0.46 & 0 & 1 & 130 \\
\hline High tech & 423 & 0.45 & 0.50 & 0 & 1 & 189 \\
\hline Other tech & 423 & 0.02 & 0.13 & 0 & 1 & 7 \\
\hline Local business partners & 421 & 0.11 & 0.32 & 0 & 1 & 48 \\
\hline Year 2005 & 423 & 0.52 & 0.50 & 0 & 1 & 221 \\
\hline Employment & 421 & 405.59 & $1,249.01$ & 6 & 19,377 & \\
\hline Age & 421 & 17.48 & 10.83 & 1 & 61 & \\
\hline Foreign capital ratio & 423 & 67.04 & 27.90 & 20 & 100 & \\
\hline
\end{tabular}

Notes: 1- Cases are included when the variable is measured as a dichotomous variable;

2- R\&D expenditure is measured in thousand Korean Won. 
Table 2 Innovation Policies and Subsidiaries' Innovation Activities

\begin{tabular}{|c|c|c|c|c|}
\hline & \multicolumn{2}{|c|}{ Model 1} & \multicolumn{2}{|c|}{ Model 2} \\
\hline & Coefficient & $\mathrm{P}>|\mathrm{z}|$ & Coefficient & $\mathrm{P}>|\mathrm{z}|$ \\
\hline \multicolumn{5}{|l|}{ Independent variables } \\
\hline All Policy & $\begin{array}{r}0.353 \\
(0.165)\end{array}$ & $\begin{array}{r}0.033 \\
(* *)\end{array}$ & $\begin{array}{r}0.170 \\
(0.152)\end{array}$ & 0.263 \\
\hline CC Sub. & & & $\begin{array}{r}1.495 \\
(0.175)\end{array}$ & $\begin{array}{l}0.000 \\
(* * *)\end{array}$ \\
\hline CE Sub. & & & $\begin{array}{r}1.210 \\
(0.168)\end{array}$ & $\begin{array}{l}0.000 \\
(* * *)\end{array}$ \\
\hline \multicolumn{5}{|l|}{ Control variables } \\
\hline lnRDStaff & $\begin{array}{r}0.009 \\
(0.095)\end{array}$ & 0.928 & $\begin{array}{r}-0.125 \\
(0.087)\end{array}$ & 0.150 \\
\hline $\operatorname{lnRDExp}$ & $\begin{array}{r}0.430 \\
(0.052)\end{array}$ & $\begin{array}{l}0.000 \\
(* * *)\end{array}$ & $\begin{array}{r}0.250 \\
(0.050)\end{array}$ & $\begin{array}{l}0.000 \\
(* * *)\end{array}$ \\
\hline Low-tech & $\begin{array}{r}0.036 \\
(0.486)\end{array}$ & 0.941 & $\begin{array}{r}0.697 \\
(0.578)\end{array}$ & 0.228 \\
\hline Medium-low tech & $\begin{array}{r}-0.347 \\
(0.522)\end{array}$ & 0.507 & $\begin{array}{r}-0.582 \\
(0.361)\end{array}$ & 0.107 \\
\hline Medium-high tech & $\begin{array}{r}0.685 \\
(0.323)\end{array}$ & $\begin{array}{r}0.034 \\
(* *)\end{array}$ & $\begin{array}{r}1.360 \\
(0.337)\end{array}$ & $\begin{array}{l}0.000 \\
(* * *)\end{array}$ \\
\hline Other tech & $\begin{array}{r}2.114 \\
(0.940)\end{array}$ & $\begin{array}{r}0.025 \\
(* *)\end{array}$ & $\begin{array}{r}0.991 \\
(0.684)\end{array}$ & 0.147 \\
\hline Business network & $\begin{array}{r}1.550 \\
(0.519)\end{array}$ & $\begin{array}{l}0.003 \\
(* * *)\end{array}$ & $\begin{array}{r}1.494 \\
(0.446)\end{array}$ & $\begin{array}{l}0.001 \\
(* * *)\end{array}$ \\
\hline Year 2005 & $\begin{array}{r}-2.491 \\
(0.309)\end{array}$ & $\begin{array}{l}0.000 \\
(* * *)\end{array}$ & $\begin{array}{r}-1.601 \\
(0.323)\end{array}$ & $\begin{array}{l}0.000 \\
(* * *)\end{array}$ \\
\hline Employment & $\begin{array}{r}0.000 \\
(0.000)\end{array}$ & $\begin{array}{l}0.000 \\
(* * *)\end{array}$ & $\begin{array}{r}0.000 \\
(0.000)\end{array}$ & $\begin{array}{l}0.000 \\
(* * *)\end{array}$ \\
\hline Entry mode & $\begin{array}{r}0.001 \\
(0.005)\end{array}$ & 0.856 & $\begin{array}{r}0.007 \\
(0.005)\end{array}$ & 0.178 \\
\hline Age & $\begin{array}{r}0.027 \\
(0.013)\end{array}$ & $\begin{array}{r}0.044 \\
(* *)\end{array}$ & $\begin{array}{r}0.030 \\
(0.015)\end{array}$ & $\begin{array}{r}0.037 \\
(* *)\end{array}$ \\
\hline Constant & $\begin{array}{r}0.119 \\
(0.551)\end{array}$ & 0.829 & $\begin{array}{r}-0.719 \\
(0.567)\end{array}$ & 0.205 \\
\hline Observations & 366 & & 356 & \\
\hline Wald chi2 (df) & $53.86(12)$ & & $\begin{array}{r}541.22 \\
(14)\end{array}$ & \\
\hline Prob $>$ chi 2 & $\begin{array}{l}0.000 \\
(* * *)\end{array}$ & & $\begin{array}{l}0.000 \\
(* * *)\end{array}$ & \\
\hline
\end{tabular}

Note:

1. Figures in parentheses are heteroscedasticity-corrected standard errors.

2. * Significance at the $10 \%$ level.

** Significance at the 5\% level.

*** Significance at the $1 \%$ level. 
Table 3 Interaction Effects between Policy and Innovation Activities

\begin{tabular}{|c|c|c|c|c|}
\hline & \multicolumn{2}{|c|}{ Model 3} & \multicolumn{2}{|c|}{ Model 4} \\
\hline & Coefficient & $\mathrm{P}>|\mathrm{z}|$ & Coefficient & $\mathrm{P}>|\mathrm{z}|$ \\
\hline \multicolumn{5}{|l|}{ Independent variables } \\
\hline All Policy & $\begin{array}{r}0.920 \\
(0.263)\end{array}$ & $\begin{array}{l}0.000 \\
(* * *)\end{array}$ & & \\
\hline CC Sub. & $\begin{array}{r}1.366 \\
(0.196)\end{array}$ & $\begin{array}{l}0.000 \\
(* * *)\end{array}$ & & \\
\hline CE Sub. & $\begin{array}{r}0.930 \\
(0.200)\end{array}$ & $\begin{array}{l}0.000 \\
(* * *)\end{array}$ & & \\
\hline \multicolumn{5}{|l|}{ Interaction terms } \\
\hline Policy \& CC Sub. & $\begin{array}{r}-0.826 \\
(0.189)\end{array}$ & $\begin{array}{l}0.000 \\
(* * *)\end{array}$ & & \\
\hline Policy \& CE Sub. & $\begin{array}{r}-0.734 \\
(0.209)\end{array}$ & $\begin{array}{l}0.000 \\
(* * *)\end{array}$ & & \\
\hline Info Supp \& CC Sub. & & & $\begin{array}{r}-0.008 \\
(0.393)\end{array}$ & 0.983 \\
\hline Info Supp \& CE Sub. & & & $\begin{array}{r}-0.157 \\
(0.435)\end{array}$ & 0.718 \\
\hline Tech Supp \& CC Sub. & & & $\begin{array}{r}-0.131 \\
(0.478)\end{array}$ & 0.784 \\
\hline Tech Supp \& CE Sub. & & & $\begin{array}{r}1.260 \\
(0.481)\end{array}$ & $\begin{array}{l}0.009 \\
(* * *)\end{array}$ \\
\hline Public Proc \& CC Sub. & & & $\begin{array}{r}-0.643 \\
(0.527)\end{array}$ & 0.222 \\
\hline Public Proc \& CE Sub. & & & $\begin{array}{r}0.362 \\
(0.443)\end{array}$ & 0.413 \\
\hline Training \& CC Sub. & & & $\begin{array}{r}0.079 \\
(0.376)\end{array}$ & 0.834 \\
\hline Training \& CE Sub. & & & $\begin{array}{r}-0.865 \\
(0.531)\end{array}$ & 0.103 \\
\hline Tax \& CC Sub. & & & $\begin{array}{r}1.520 \\
(0.378)\end{array}$ & $\begin{array}{l}0.000 \\
(* * *)\end{array}$ \\
\hline Tax \& CE Sub. & & & $\begin{array}{r}0.272 \\
(0.347)\end{array}$ & 0.433 \\
\hline Public Funding \& CC Sub. & & & $\begin{array}{r}-0.303 \\
(0.546)\end{array}$ & 0.580 \\
\hline Public Funding \& CE Sub. & & & $\begin{array}{r}0.039 \\
(0.411)\end{array}$ & 0.924 \\
\hline Control variables & & & & \\
\hline lnRDStaff & $\begin{array}{r}-0.204 \\
(0.087)\end{array}$ & $\begin{array}{r}0.019 \\
(* *)\end{array}$ & $\begin{array}{r}-0.052 \\
(0.095)\end{array}$ & 0.586 \\
\hline $\operatorname{lnRDExp}$ & $\begin{array}{r}0.289 \\
(0.049)\end{array}$ & $\begin{array}{l}0.000 \\
(* * *)\end{array}$ & $\begin{array}{r}0.492 \\
(0.061)\end{array}$ & $\begin{array}{l}0.000 \\
(* * *)\end{array}$ \\
\hline Low-tech & $\begin{array}{r}0.887 \\
(0.545)\end{array}$ & 0.104 & $\begin{array}{r}0.210 \\
(0.482)\end{array}$ & 0.664 \\
\hline Medium-low tech & $\begin{array}{r}-0.356 \\
(0.373)\end{array}$ & 0.341 & $\begin{array}{r}-0.137 \\
(0.595)\end{array}$ & 0.818 \\
\hline Medium-high tech & $\begin{array}{r}1.222 \\
(0.310)\end{array}$ & $\begin{array}{l}0.000 \\
(* * *)\end{array}$ & $\begin{array}{r}0.380 \\
(0.332)\end{array}$ & 0.252 \\
\hline
\end{tabular}




\begin{tabular}{l|rr|rr} 
Other tech & 0.789 & 0.147 & 2.665 & 0.008 \\
& $(0.544)$ & & $(1.002)$ & $(* * *)$ \\
Local partner & 1.173 & 0.004 & 1.643 & 0.009 \\
& $(0.406)$ & $(* * *)$ & $(0.626)$ & $(* * *)$ \\
Year 2005 & -1.880 & 0.000 & -2.163 & 0.000 \\
Employment & $(0.320)$ & $(* * *)$ & $(0.359)$ & $(* * *)$ \\
& 0.000 & 0.000 & 0.000 & 0.009 \\
Foreign capital ratio & $(0.000)$ & $(* * *)$ & $(0.000)$ & $(* * *)$ \\
& 0.009 & 0.066 & -0.003 & 0.606 \\
Age & $(0.005)$ & $(*)$ & $(0.006)$ & \\
& 0.033 & 0.010 & 0.020 & 0.159 \\
Constant & $(0.013)$ & $(* *)$ & $(0.014)$ & \\
& -0.470 & 0.413 & -0.212 & 0.722 \\
\hline \multirow{2}{*}{ Observations } & $(0.574)$ & & $(0.594)$ & \\
Wald chi2 (df) & 356 & & 356 & \\
Prob > chi2 & $520.19(16)$ & & 288.59 & \\
& & & $(23)$ & \\
\hline
\end{tabular}

Notes:

1. Figures in parentheses are heteroscedasticity-corrected standard errors.

2. * Significance at the $10 \%$ level.

** Significance at the $5 \%$ level.

*** Significance at the $1 \%$ level

3. $\mathrm{CE}=$ Competence Exploiting Subsidiaries; $\mathrm{CC}=$ Competence Creating Subsidiaries 


\section{References}

Almeida, P. \& Phene, A. (2004) Subsidiaries and knowledge creation: the influence of the MNC and host country on innovation. Strategic Management Journal 25 (8/9): 847.

Andersson, U., Forsgren, M. \& Holm, U. (2002) The strategic impact of external networks: Subsidiary performance and competence development in the multinational corporation. Strategic Management Journal 23 (11): 979-996.

Aschhoff, B. \& Sofka, W. (2009) Innovation on demand: Can public procurement drive market success of innovation? . Research Policy 38: 1235-1247.

Birkinshaw, J. \& Hood, N. (1998) Multinational Subsidiary evolution: Capability and charter change in foreign-owned subsidiary companies. Academy of Management Review 23 (4): 773-795.

Birkinshaw, J. \& Hood, N. (2001) Unleash innovation in foreign subsidiaries. Harvard Business Review 79 (3): 131.

Bodas Freitas, I. M. \& Tunzelmann, N. v. (2008) Mapping public support for innovation: A comparison of policy alignment in the UK and France. Research Policy 37 (9): 1446-1464.

Cantwell, J. (2009) Location and the multinational enterprise. Journal of International Business Studies 40 $(1): 35$.

Cantwell, J. \& Mudambi, R. (2005) MNE competence-creating subsidiary mandates. Strategic Management Journal 26 (12): 1109.

Cantwell, J. \& Piscitello, L. (2002) The location of technological activities of MNCs in European regions: The role of spillovers and local competencies. Journal of International Management 8 (1): 69-96.

Cantwell, J., \& Mudambi, R. (2000) The location of MNE R\&D activity: The role of Investment Incentives. Management International Review 40 (1): 127-148.

Cassiman, B. \& Veugelers, R. (2002) R\&D cooperation and spillovers: Some empirical evidence from Belgium. American Economic Review 92 (4): 1169-1184.

Casson, M. (2007) Multinational enterprises: Their private and social benefits and costs. The World Economy 30 (2): 308-328.

Chung, S. \& Shavinina, L. V. (2003) Innovation in Korea. In:The International Handbook on Innovation. Oxford: Pergamon, pp: 890-903.

Crespi, G., Criscuolo, C., Haskel, J. E. \& Slaughter, M. (2007) Productivity Growth, Knowledge Flows and Spillovers. London, London School of Economics and Political Science, Centre for Economic Performance (CEP) Discussion Paper No 785.

DiMaggio, P. J. \& Powell, W. W. (1983) The iron cage revisited: institutional isomorphism and collective rationality in organizational fields. American Sociological Review 48 (2): 147-160.

Dunning, J. H. \& Lundan, S. M. (2008) Multinational Enterprises and the Global Economy. Cheltenham, Northampton: Edward Elgar.

Eden, L. \& Miller, S. R. (2004) Distance matters: Liability of foreigness, institutional distance and ownership strategy. Bush School Working Paper \# 404. Texas A\&M University.

Forsgren, M., Holm, U. \& Johanson, J. (2005) Managing the Embedded Multinational: A Business Network View. Cheltenham: Edward Elgar.

Foss, N. J. \& Pedersen, T. (2002) Transferring knowledge in MNCs: The role of sources of subsidiary knowledge and organizational context. Journal of International Management 8 (1): 49-67.

Francis, J., Zheng, C. \& Mukherji, A. (2009) An institutional perspective on Foreign Direct Investment: A multi-level framework. Management International Review 49 (5): 565-583.

Frost, T. S. (2001) The geographic sources of foreign subsidiaries' innovations. Strategic Management Journal 22 (2): 101-123.

Frost, T. S., Birkinshaw, J. M. \& Ensign, P. C. (2002) Centers of excellence in multinational corporations. Strategic Management Journal 23 (11): 997.

Gaur, A. S. \& Lu, J. W. (2007) Ownership strategies and survival of foreign subsidiaries: Impacts of institutional distance and experience. Journal of Management 200733 (1): 84-110.

Ghauri, P. N. \& Yamin, M. (2009) Revisiting the impact of multinational enterprises on economic development. Journal of World Business 44 (2): 105-107. 
Ghauri, P. N., Hadjikhani, A., \& Johanson, J. (Eds.). (2005) Managing Opportunity Development in Business Networks. Basingstoke: Palgrave McMillan.

Ghoshal, S. \& Bartlett, C. A. (1988) Creation, adoption, and diffusion of innovations by subsidiaries. Journal of International Business Studies 19 (3): 365.

Giroud, A. (2006) Is government support really worth it? Developing backward linkages in Malaysia. In. Tavares, A. \& Teixeira, A. A. C. (eds.) Multinationals, Clusters and Innovation: Does Public Policy Matter? : Palgrave MacMillan., pp: 179-198.

Guimón, J. (2011) Policies to benefit from the globalization of corporate R\&D: An exploratory study for EU countries. Technovation 31 (2-3): 77-86.

Hobday, M. (1995) Innovation in East sia: Challenge to Japan. Aldershot, UK: Edward Elgar

Jones, R. S. \& Yoon, T. (2008) Enhancing the globalisation of Korea Economic Department Working Papers. Paris, OECD.

Kim, L. (2003) Dynamics of technology development: lessons from the Korean experience. In. Lall, S. \& Urata, S. (eds.) Competitiveness, FDI and Technology Activity in East Asia. Cheltenham: Edward Elgar, pp.

KOITA (2007) Analysis of R\&D by foreign invested-companies and policy implications. Policy report. Seoul, KOITA.

Kostova, T. (1999) Transnational transfer of strategic organizational practices: a contextual perspective. Academy of Management Review 24 (2): 306-324.

KOTRA (2007) FDI Promotion White Paper. Seoul, Korea: Ministry of Commerce, Industry and Energy / KOTRA.

Lall, S. (2003) Foreign direct investment, technology development and competitiveness: Issues and evidence. In. Lall, S. \& Urata, S. (eds.) Competitiveness, FDI and Technology Activity in East Asia. Chelteham: Edward Elgar, pp.

Lee, I. H. \& Rugman, A. M. (2009) Multinationals and public policy in Korea Asian Business \& Management 8 (1): 59-82.

Lee, J. \& Park, C. (2006) Research and development linkages in a national innovation system: Factors affecting success and failure in Korea. Technovation 26 (9): 1045-1054.

Lim, S.-H. (2008) How investment promotion affects attracting foreign direct investment: Analytical argument and empirical analyses. International Business Review 17: 39-53.

Lundvall, B. A. (1992) National Systems of Innovation: Towards a Theory of Innovation and Interactive Learning. London Pinter.

Marin, A. \& Bell, M. (2006) The local/global integration of MNC subsidiaries and their technological behaviour: Argentina in the late 1990s. Research Policy 39 (7): 919-931.

Meyer-Krahmer, F. \& Reger, G. (1999) New perspectives on the innovation strategies of multinational enterprises: lessons for technology policy in Europe. Research Policy 28 (7): 751-776.

Mudambi, R. \& Mudambi, S. M. (2005) Multinational enterprise knowledge flows: The effect of government inward investment policy. Management Internatoinal Review 45 (2): 155-178.

Narula, R. (2002) Innovation systems and 'inertia' in R\&D location: Norwegian firms and the role of system lock-in. Research Policy 31 (5): 795-816.

North, D. C. (1990) Institutions, Institutional Change and Economic Performance. Cambridge: Cambridge University Press.

OECD (2009a) Main Science and Technology Indicators Volume 2. Paris: OECD.

OECD (2009b) OECD Reviews of Innovation Policy: Korea. Paris, OECD,.

Oliver, C. (1991) Strategic responses to institutional processes. The Academy of Management Review 16 (1): 145-179.

Pearce, R. (1999) The evolution of technology in multinational enterprises: the role of creative subsidiaries. International Business Review 8 (2): 125-148.

Phene, A. \& Almeida, P. (2003) How do firms evolve? The patterns of technological evolution of semiconductor subsidiaries. International Business Review 12 (3): 349-367. 
Roper, S., Du, J. \& Love, J. H. (2008) Modelling the innovation value chain. Research Policy 37: 961977.

Rosenzweig, P. M. \& Nohria, N. (1994) Influences on human resource management practices in multinational corporations. Journal of International Business Studies 25 (2): 229-251.

Rosenzweig, P. M. \& Singh, J. V. (1991) Organizational environments and the multinational enterprise. The Academy of Management Review 16 (2): 340-361.

Santangelo, G. D. (2009) MNCs and linkages creation: Evidence from a peripheral area. Journal of World Business 44 (2): 198-191.

Schmiedeberg, C. (2008) Complementarities of innovation activities: An empirical analysis of the German manufacturing sector. Research Policy 37: 1492-1503.

Shin, T.-y., Song, J.-g., Ahn, D.-h., Lee, W.-s., Chung, S.-i., Sohn, C.-w., Sohn, S.-j., Kim, H.-h., Hur, H.h. \& Han, K.-i. (2006) A Comprehensive Appraisal of Policy Support Programs for technological Innovation. Seoul, Korea, Science and Technology Policy Institute (STEPI).

Sofka, W. (2006) Innovation activities abroad and the effects of liability of foreignness: Where it hurts. Manheim, Germany, Centre for European Economic Research (ZEW) Discussion Paper No. 06029.

Wooldridge, J. M. (2002) Econometric Analysis of Cross Section and Panel Data. Cambridge, Massachusetts: The MIT Press.

Wooldridge, J. M. (2009) Introductory Econometrics, Fourth Edition. South-Western Cengage Learning.

Yamin, M. (1999) An Evolutionary Analysis of Subsidiary Innovation and 'Reverse' Transfer in Multinational Companies. In. Burton, F. N., Chapman, M. \& Cross, A. (eds.) International Business Organization: Subsidiary Management, Entry Strategies and Emerging Markets. Basingstoke: MacMillan Press, pp: 67-82.

Yamin, M. \& Andersson, U. (2011) Subsidiary importance in the MNC: What role does internal embeddedness play? International Business Review In Press, Corrected Proof.

Yamin, M. \& Otto, J. (2004) Patterns of knowledge flows and innovative performance in MNEs. Journal of International Management 10 (2): 239-258.

Zaheer, S. (1995) Overcoming the liability of foreignness. The Academy of Management Journal 38 (2): 341-363. 